\title{
Kapinus $O$. S. The use of contextual learning technology in shaping the future subject officer's professional
} personality

The article analyzes the actual pedagogical problem of using contextual learning technology in the process of forming the professional subjectivity of future officers of the Armed Forces of Ukraine during training in higher military educational establishments, finding ways to implement a contextual approach to its formation using the potential of a contextual approach to the organization of educational process.

Emphasis is placed on the need to find ways to individualize the educational process and to provide the conditions for self-realization of the cadet as a military professional and personality at different stages of service, since the expected result of higher military education for future officers is the formation of professional subjectivity, the direct manifestation of which is the proper manifestation of being object, perceive the subjectivity of other servicemen, purposefully form and translate it in their activities and the ability of the future the officer adequately addresses the pressing issues inherent in the troops.

The advantages of the contextual approach to the organization of educational process in higher military education are summarized, which include significant potential in the formation of both knowledge, skills and professionally important qualities that make up the professional competence of a specialist in accordance with current needs, ensuring transformation-educational activities in the professional field, promoting the development of professional thinking of the cadet through the definition of a specific vocational-oriented learning goal, prompt response. Ineed real military officer professional activities by amending and correcting the content of programs of training courses to meet the requirements of the profession.

The components of the contextual approach that are most appropriate for use in the educational process of a higher military educational establishment during the formation of professional subjectivity of a future officer are identified: construction of a contextual educational environment of a higher military educational institution, quasi-professional analysis of situational problems professional activity.

Key words: cadet, future officer, subject, context, contextual approach, educational process, higher military education.

УДК 378.1:34

DOI https://doi.org/10.31392/NPU-nc.series5.2019.71.30

Келемен Р. Ю.

\section{СТРУКТУРНО-ФУНКЦІОНАЛЬНА МОДЕЛЬ ПІДГОТОВКИ МАЙБУТНІХ МОЛОДШИХ СПЕЦІАЛІСТІВ ІЗ ПРАВОЗНАВСТВА ЗАСОБАМИ ІНТЕРАКТИВНИХ ТЕХНОЛОГІЙ}

В умовах сьогодення існує гостра необхідність у радикальній трансформації соціальної юриспруденції та реалізації принципово нових підходів до здійснення фахової підготовки майбутніх молодиих спеціалістів з правознавства. Оптимальним шляхом для реалізації такого завдання є спрямованість вектора правничої освіти до професійного навчання майбутніх молодших спеціалістів з правознавства засобами інтерактивних технологій, детермінуючи їхню здатність до відтворення норм і правил юридичної професії. Заклад освіти юридичного профілю як інструмент змін, індикатор правового життя держави в умовах сьогодення отримує замовлення на правознавия, здатного успішно й ефективно вирішувати професійні завдання будь-якого рівня складності.

У статті розкрито сучасну ситуацію розвитку юридичної освіти в умовах зростаючих вимог до сучасного фахівия. Сукупність спеціальних педагогічних заходів, спрямованих на формування професійної компетентності майбутніх молодиих спеціалістів з правознавства у процесі фахової підготовки засобами інтерактивних технологій, є структурно-функціональною моделлю, яка відображає иілісний, поліструктурний та синергійний характер юридичного освітнього процесу. Розроблена й науково обтрунтована модель містить мету та завдання, принции, зміст, компонентну структуру феномену, який досліджується, педагогічні умови, зміст, форми й методи підготовки майбутніх правників; критерії та рівні професійної компетентності майбутніх молодших спеціалістів з правознавства та кінцевий результат - сформованість професійної компетентності.

Результат реалізачії авторської моделі як фундаментальної стратегії змін, глибоке осмислення та розв'язання проблеми формування професійної компетентності майбутніх молодших спеціалістів з правознавства у процесі фахової підготовки засобами інтерактивних технологій надає можливість створити оптимальне освітнє середовище формування та розвитку сучасного правника-професіонала.

Ключові слова: підготовка майбутніх молодших спеціалістів з правознавства, інтерактивні технології, структурно-функиіональна модель, професійна компетентність, педагогічне моделювання.

Обгрунтування теоретичних основ досліджуваного процесу, потенційних можливостей інтерактивних технологій, змісту, структури професійної компетентності майбутніх молодших спеціалістів 3 правознавства (далі - МСП) в освітньому середовищі закладів юридичної освіти уможливили розробку педагогічної моделі, яка є сукупністю пов'язаних за змістом і термінами ресурсів, спрямованих на формування професійної компетентності майбутніх МСП; поєднує теоретичне і практичне навчання; є наскрізною, що застосовується протягом усього періоду навчання.

Метою статті $є$ розгляд структурно-функціональної моделі підготовки майбутніх молодших спеціалістів із правознавства засобами інтерактивних технологій.

Аналіз моделювання процесу підготовки майбутніх МСП засобами інтерактивних технологій вимагає визначення змісту поняття «модель», яким автор буде оперувати в межах дослідження. У його розумінні 
існує кілька підходів, пов'язаних із різноаспектними напрямами моделювання характеристик і властивостей об'єктів, які досліджуються [1, с. 130].

Теоретичний аналіз наукових джерел дає змогу узагальнити, що використання методу наукового моделювання як способу інноваційних перетворень професійної підготовки майбутніх МСП передбачає концептуально-теоретичне, процесуально-технологічне забезпечення створення інноваційної освітньої моделі підготовки майбутніх МСП засобами інтерактивного навчання та їі поступовий перехід у режим поліфункціонального, полісистемного саморозвитку [2, с. 144]. Важливою методологічною передумовою до визначення змісту моделювання процесу, що досліджується, є положення В. Штофа про модель як кінцеву систему, що є проміжною ланкою між теорією і дійсністю [5, с. 170].

Варто зазначити і деяку подвійність педагогічних моделей, які мають аксіоматичний складник, заснований на загальних педагогічних закономірностях і загальній методології, а також змістовну частину, засновану на конкретному педагогічному досвіді [4, с. 84]. Відтак, педагогічні моделі практично завжди вирізнялися новизною, однак не забезпечували валідності без експериментальної перевірки і підтвердження.

Проектована структурно-функціональна модель підготовки майбутніх молодших спеціалістів 3 правознавства засобами інтерактивних технологій розглядається як методична схема динамічного процесу формування професійної компетентності в логіці руху «від мети до результату» шляхом обгрунтування цільового аспекту, завдань, змісту, методів, принципів, діагностики професійно-освітньої діяльності з формування професійної компетентності майбутніх МСП. Загалом структурно-функціональна модель підготовки майбутніх молодших спеціалістів з правознавства засобами інтерактивних технологій поєднує теоретико-концептуальну (зміст моделі) та методико-технологічну частину (обгрунтування структурних компонентів моделі, якими є мета, завдання, методи, принципи, діагностика).

Структура і зміст структурно-функціональної моделі підготовки майбутніх МСП засобами інтерактивних технологій виявляється в системно-цілісній спрямованості підготовки особистості студента, що володіє встановленим набором професійних компетенцій, необхідних для входження на сучасний ринок праці.

Розуміння структурно-функціональної моделі підготовки майбутніх МСП засобами інтерактивних технологій як еталонного зразка передбачає відображення об'єкта, процесу і продуктів моделювання в межах таких блоків:

1) цільового, спрямованого на формування професійної компетентності майбутніх МСП засобами інтерактивних технологій;

2) змістовно-методологічного, що охоплює завдання, провідні наукові принципи та обрані для дослідження дисципліни, що визначають процес формування професійної компетентності в межах професійної підготовки майбутніх МСП засобами інтерактивного навчання і забезпечують його методологічний та науково-методичний супровід;

3) процесуально-технологічного, що містить форми, методи, засоби навчання, педагогічні умови;

4) критеріально-результативного, який передбачає здійснення моніторингу сформованості професійної компетентності майбутніх МСП.

Кожен блок представлений функціями, призначення яких сприяє уточненню структури певної моделі. Організаційна функція моделі визначає процес організації підготовки майбутніх МСП засобами інтерактивного навчання згідно з виділеними принципами, педагогічними умовами, формами і методами навчання. Розвивальна функція полягає не лише у формуванні правових знань, спеціальних умінь, а й у стимулюванні пізнавальної активності, творчого саморозвитку, формуванні компонентів професійної компетентності студентів. Управлінська функиія спрямована на рефлексивну взаємодію (співуправління) суб' єктів освітнього процесу, формування у студентів здатності до планування, самоорганізації та самоврядування власною навчально-професійною діяльністю. Оцінювально-результативна функція спрямована на діагностику рівнів сформованості професійної компетентності майбутніх МСП за якісними і кількісними змінами в ㄲi компонентах; визначення результативності формування феномену, який досліджується, засобами інтерактивних технологій.

Цільовий блок є об'єднувальним елементом проектованої моделі. У межах дослідження автор визначає стратегічну мету формування професійної компетентності майбутніх МСП, що передбачає вдосконалення якості професійної підготовки в закладах юридичної освіти засобами інтерактивних технологій. Тактична мета пов'язана 3 визначенням рівня сформованості професійної компетентності майбутніх МСП. Тобто, цільовий блок, будучи об'єднувальним (системотвірним), пов'язаний внутрішніми системними зв' язками 3 усіма іншими блоками, визначаючи їхні функції та зміст. Змістовно-методологічний блок відображає взаємозв'язок і взаємодію завдань дослідження, принципів та змісту підготовки майбутніх МСП засобами інтерактивних технологій.

3 метою досягнення поставленої в межах дослідження мети визначено такі завдання підготовки майбутніх МСП засобами інтерактивних технологій:

1) забезпечення умов для інтеграції інтерактивних і традиційних технологій навчання, оптимального використання їхнього потенціалу в процесі професійної підготовки майбутніх молодших спеціалістів з правознавства;

2) сприяння індивідуалізації освітнього процесу та оптимізації взаємодії його суб'єктів; 
3) забезпечення ефективності педагогічного супроводу самостійної пізнавальної діяльності студентів.

Побудова та обгрунтування структурно-функціональної моделі підготовки майбутніх МСП засобами інтерактивного навчання не може здійснюватися без використання сукупності принципів, імплементація яких дасть змогу послідовно охарактеризувати процес формування професійної компетентності, виокремити категоріальні блоки структури, динаміки, рівнів, етапів, умов ефективності цього процесу та продуктивності його результату.

Стратегічною умовою оновлення освіти майбутніх МСП у контексті цього дослідження $\epsilon$ реалізація таких принципів навчання: професійно зорієнтованої спрямованості підготовки майбутніх МСП; ситуативності навчання майбутніх МСП; ключової ролі спільної діяльності на основі міжособистісної взаємодії і діалогічного спілкування суб'єктів освітнього процесу; врахування індивідуально-психологічних особливостей студентів у процесі підготовки до професійної діяльності; формування професійних навичок для роботи щодо здійснення різних видів професійної діяльності.

У змісті підготовки майбутніх МСП засобами інтерактивних технологій виокремлено такі складники:

1) освоєння змісту правових знань щодо особливостей професійної діяльності майбутніх МСП на сучасному етапі, а також знань щодо технологій соціальної взаємодії в юридичній діяльності;

2) оволодіння сукупністю теоретичних і практичних умінь для організації навчально-професійної діяльності;

3) оволодіння досвідом творчої діяльності у вирішенні професійно зорієнтованих правових проблем в юридичній діяльності;

4) оволодіння досвідом емоційно-ціннісного ставлення до професійної юридичної діяльності (нормотворча, правоохоронна, правозастосувальна та експертно-консультаційна).

Процес професійної підготовки майбутніх МСП повинен бути наповнений змістом, який відповідає основним цілям навчання. Тому, розкриваючи змістовний аспект інтерактивного навчання й зосереджуючи увагу на його розвивальному характері, основним критерієм відбору змісту професійної підготовки та іï структури в навчальних дисциплінах професійного та практичного циклів, автор виокремлює проблемність. Зміст навчання 3 дисциплін «Кримінальне право», «Цивільне право», «Діловодство (юридична клініка)», «Конституційне право України» проектується у вигляді проблемних ситуацій та похідних від них навчальних завдань, в основі яких лежить проблематизація.

Процесуально-технологічний блок структурно-функціональної моделі передбачає сукупність дій суб'єктів освітнього процесу, спрямованих на формування професійної компетентності майбутніх МСП. Це взаємозв'язок форм і методів навчання, що оптимально сприяють реалізації спроектованого змісту підготовки майбутніх МСП засобами інтерактивного навчання. Новий сконструйований зміст навчального матеріалу з обраних для дослідження дисциплін професійного та практичного циклу передбачає використання нових форм навчання, тобто зміст визначає форми, в яких він засвоюється [3, с. 191]. Процесуально-технологічний блок орієнтує підготовку майбутніх МСП на інший підхід до використання інтерактивних технологій, ідентичний цілям, завданням, змісту формування професійної компетентності та змісту досліджуваного матеріалу.

Важливе місце в процесуально-технологічному блоці структурно-функціональної моделі підготовки майбутніх МСП засобами інтерактивних технологій посідають педагогічні умови:

1) занурення студентів у професійно зорієнтоване мотиваційне середовище шляхом використання інтерактивних технологій;

2) міждисциплінарна інтеграція дисциплін професійно-практичного циклу шляхом використання інтерактивних форм і методів навчання;

3) практико зорієнтована спрямованість підготовки майбутніх молодших спеціалістів 3 правознавства в коледжах;

4) активізація індивідуалізованої самоосвітньої діяльності студентів засобами інтерактивних технологій.

Критеріально-результативний блок є синтезом компонентів (аксіологічний, когнітивний, діяльнісний, рефлексивний) i критеріїв (мотиваційно-аксіологічний, когнітивно-змістовний, діяльнісно-практичний, оцінювально-рефлексивний), що визначають рівні (високий, достатній, задовільний, низький) сформованості професійної компетентності майбутніх МСП, а також очікувані результати. Окреслений блок заснований на виявленні елементів структури професійної компетентності майбутніх МСП, визначенні їхнього взаємозв'язку і положення стосовно один одного.

Висновки. Таким чином, розроблена структурно-функціональна модель підготовки майбутніх МСП засобами інтерактивних технологій є складною багаторівневою системою і має низку взаємопов'язаних і взаємозалежних блоків, що охоплюють необхідні для формування професійної компетентності елементи: изільовий (мета, завдання); змістовно-методологічний (принципи); процесуально-технологічний (компоненти, етапи формування професійної компетентності, форми, методи, засоби навчання, педагогічні умови); критеріально-результативний блоки (компоненти, критерії та рівні сформованості професійної компетентності, результат).

Перспективи подальших наукових розвідок автор вбачає у розробці необхідного навчально-методичного забезпечення для впровадження розробленої структурно-функціональної моделі в освітній процес професійної підготовки майбутніх молодших спеціалістів 3 правознавства. 


\section{Використана література:}

1. Бірюков О. М. Дворівнева модель підготовки юристів: погляду майбутнє. Юридичнагазета. 2016. Вип. 26 (524). С. $125-137$.

2. Котикова О. М. Практико-зорієнтована психолого-педагогічна підготовка майбутніх юристів : монографія. К. : КНЕУ, 2010. $343 \mathrm{c}$

3. Радченко К. Профіль професійної компетентності майбутнього військового юриста. Військова освіта. Збірник наукових праць Національного університету оборони України ім. I. Черняховського. 2017. Вип. 2 (36). С. 188-198.

4. Сабатовська І. С., Кайдалова Л. Г. Моделювання діяльності фахівця : навч. посібн. Х. : НФаУ, 2014. 180 с.

5. Штофф В. А. Моделирование и познание. Минск, 1977. 178 с.

\section{References:}

1. Biriukov O. M. (2016), «Dvorivneva model pidhotovky yurystiv: pohliad u maibutnie» [Two-level model of legal training: look into the future]. Legal newspaper. 2016. Issue 26 (524). pp. 125-137. [in Ukrainian].

2. Kotykova O. M. (2010), Praktyko-zoriientovana psykholoho-pedahohichna pidhotovka maibutnikh yurystiv [Practically oriented psychological and pedagogical training of future lawyers], monograph. Kyiv : KNEU. 343 p. [in Ukrainian].

3. Radchenko K. (2017), «Profil profesiinoi kompetentnosti maibutnoho viiskovoho yurysta» [Profile of professional competence of future military lawyer]. Military education. Research papers collection of the National Defence University of Ukraine named after Ivan Cherniakhovskyi. 2017. Issue 2 (36). pp. 188-198. [in Ukrainian].

4. Sabatovska I. S., Kaidalova L. H. (2014), Modeliuvannia diialnosti fakhivtsia [Modeling of specialist's activity], study tool. Kharkiv : NFaU. 180 p. [in Ukrainian].

5. Stoff V. A. (1977), Modelirovanie i poznanie [Modeling and cognition]. Minsk. 178 p. [in Russian].

Kelemen R. Y. Structural-functional model of training of future junior specialists in law by means of interactive technologies

Today, there is an urgent need for a radical transformation of social jurisprudence in general, and for the implementation of fundamentally new approaches to the vocational training of future junior specialists in law, in particular. The optimal way for realization of such task is direction of vector of legal education by means of interactive technologies, determining their ability to reproduce the rules and regulations of the juridical profession. After all, the institution of education of the juridical profile as a tool for change, an indicator of the legal life of state in the nowadays conditions receives an order for a lawyer who is able to successfully and effectively solve professional tasks of any level of complexity.

The article deals with the modern situation of development of legal education in the conditions of growing requirements to modern specialist. The complex of special pedagogical activities, directed on the formation of professional competence of future junior specialists in law in the process of vocational training by means of interactive technologies, presents a structural-functional model, which reflects the holistic, multi-structural and synergistic nature of the legal educational process. The developed and scientifically substantiated model contains purpose and tasks, principles, content, component structure of the studied phenomenon, pedagogical conditions, essence, forms and methods of training of future junior specialists in law and the final result - the formation of professional competence.

The result of implementation of author's model as a fundamental strategy of changes, deep understanding and resolution of the problem of formation of professional competence of future junior specialists in law in the process of vocational training by means of interactive technologies gives the opportunity to create optimal educational environment of formation and development of modern lawyer-professional.

Key words: training of future junior specialists in law, interactive technologies, structural-functional model, professional competence, pedagogical modeling.

УДК 780.614.131:37.013.3(477)(09)

DOI https://doi.org/10.31392/NPU-nc.series5.2019.71.31

Коваленко А. С.

\section{РОЛЬ ФЛАМЕНКО У РОЗВИТКУ ГІТАРНОЇ ОСВІТИ УКРАЇНИ}

Здійснено історіографічний аналіз витоків мистеитва фламенко на території України та його вплив на розвиток вітчизняної гітарної освіти. Застосувавщи методи історико-педагогічного аналізу та системного підходу, розглянуто наукові прачі провідних учених галузі. Визначено, щь фламенко - це мистечтво, яке, поєднавщи елементи культур інших народів, сформувало власну оригінальну структуру: вокал, хореографію та гітарний супровід. Доведено, щзо ичей феномен, сформувавшись в Іспанії, ивидко набув поширення у світовому та українському просторі.

Встановлено, що на етапі становлення мистецтва фламенко техніка гітариста була досить примітивною, проте з початком епохи «саfе cantante» роль гітари значно зросла, і виконавська техніка потребувала вдосконалення. Сучасні гітаристи фламенко, які супроводжують спів та таниі, чудово імпровізують, незважаючи на те, щуо зазвичай не мають академічної музичної освіти. Віртуозність, необхідна для виконання деяких творів, дозволяє гітаристові легко перейти від акомпанементу до сольної гри.

Вітчизняне мистецтво фламенко розвивав та примножував А. Шевченко. Твори, які він написав для гітари, поповнили репертуар українських гітаристів та збагатили їх виражальні можливості. Визначну роль у подальшому розвитку мистецтва фламенко в Україні зіграла організаторська діяльність А. Шевченка, під впливом якої багато талановитої молоді продовжує розвивати ичю культурну традицію. 